\title{
Evaluation of Acute Pancreatitis Patients: Single Center Five Years' Experience
}

\author{
Akut Pankreatitli Olgularımız: Tek Merkez Beş Yıllık Deneyim

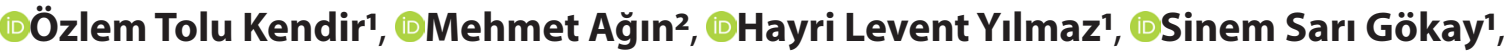 \\ Gökhan Tumgor ${ }^{2}$ \\ 'Çukurova University, Pediatrics, Emergency Care Unit, Balcalı Hospital Adana, Turkey \\ ${ }^{2}$ Cukurova University, Pediatric Gastroenterolology, Balcalı Hospital Adana, Turkey
}

\begin{abstract}
Aim: In the present study, the purpose was to examine the clinical and laboratory characteristics of patients diagnosed with acute pancreatitis in a third-line Children's Emergency Department, and to draw attention to the importance of acute pancreatitis in the differential diagnosis of children admitting with abdominal pain.

Material and Method: The children or the patients who were diagnosed with acute pancreatitis at Çukurova University Faculty of Medicine, Department of Pediatric Emergency Medicine for a period of 5 years were included in the study. The patients were divided into two groups as acute pancreatitis and recurrent acute pancreatitis. The clinical and laboratory data of the patients were examined retrospectively. Acute pancreatitis risk factors were determined according to the Modified Ranson Criteria.

Results: A total of 53 patients who were diagnosed with acute pancreatitis were included in the study. The patients had attacks for a total of 116 times. The mean age of the patients was $10.6 \pm 4.4$ years (minimum: 0.5, maximum: 17.5), 28 (52.8\%) were girls, and 22 (41.5\%) had $\geq 2$ attacks. The etiology of acute pancreatitis could not be determined in 20 (38\%) patients, and hyperlipidemia was detected in 10 patients (18.8\%).

Conclusion: Acute Pancreatitis should be considered in the differential diagnosis of patients admitting to Emergency Departments with abdominal pain, and the awareness about the subject should be increased.
\end{abstract}

Keyword: Acute pancreatitis, acute recurrent pancreatitis, abdominal pain
Öz

Amaç: Bu çalışmada; üçüncü basamak bir çocuk acil ünitesinde akut pankreatit tanısı almış hastaların klinik ve laboratuvar özelliklerinin incelenmesi, karın ağrılı çocuk hastaların ayıııcı tanısında akut pankreatitin önemine dikkat çekilmesi amaçlanmıştır.

Gereç ve Yöntem: Çalışmaya Çukurova Üniversitesi Tıp Fakültesi Çocuk Acil Bilim Dalı́nda 5 yıllık sürede akut pankreatit tanısı almış çocuk hastalar dahil edildi. Hastalar akut ve tekrarlayan akut pankreatit olarak iki gruba ayrıldı. Hastaların klinik ve laboratuvar verileri geriye dönük incelendi. Modifiye Ranson kriterlerine göre akut pankreatit risk faktörleri belirlendi.

Bulgular: Çalışma süresince akut pankreatit tanısı alan 53 hasta çalışmaya alındı. Hastalar toplamda 116 kez atak geçirmişti. Yaş

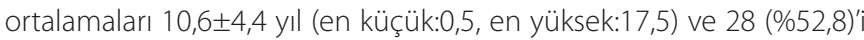
kIz idi. 22'si $(\% 41,5) \geq 2$ atak geçirmişti. Akut pankreatit etiyolojisi 20 (\%38) hastada belirlenemez iken, 10 hastada (\%18,8) hiperlipidemi saptandı.

Sonuç: Çocuk acil servislere karın ağrısı ile başvuran hastaların ayıııı tanısında akut pankreatit düşünülmeli, konu ile ilgili farkındalık arttırılmalıdır.

Anahtar Kelime: Akut pankreatit, akut tekrarlayan pankreatit, karın ağrısı 


\section{INTRODUCTION}

Acute Pancreatitis (AP) is the pancreatic inflammation characterized by pathological changes of different severity, from mild edematous interstitial form to severe necrotizing pancreatitis. ${ }^{[1-5]}$ It was reported in previous studies that the incidence of AP increases worldwide, especially in Scandinavian countries, with an annual increase of 3.6-13.8/100000. ${ }^{[2-8]}$ $\mathrm{AP}$, which constitutes a small but significant part of Child Emergency Department admissions, is considered to be associated with causes such as trauma, infection, medication, metabolic disorder, autoimmune disease, and it is reported that its incidence has increased in recent years. ${ }^{[1,9,10]}$

There are a limited number of studies conducted in Turkey reflecting the frequency and etiology of AP in children. In this study, the etiology, clinical, radiological imaging, and laboratory data of the children who were diagnosed with AP were evaluated in a Third-Line Children's Emergency Department, which serves a wide area. The importance of early recognition of AP in Children's Emergency Departments and the early initiation of treatment were emphasized in the present study.

\section{MATERIAL METHOD}

The patients diagnosed with pancreatitis at Çukurova University Faculty of Medicine Children's Emergency Department between January 2012 and 2016, with archival records available were included in the study. The diagnosis of AP in the Emergency Department was made with the presence of at least two of the following criteria, sudden abdominal pain, serum amylase and/or lipase levels being elevated three times higher than normal, and changes in the pancreas supported by radiological methods. ${ }^{[1,4]}$ (Amylase laboratory reference range: 28-100 U/L) (Lipase laboratory reference range: 22-51 U/L). The patients with single attack were defined as $A P$, and those with 2 and more attacks with fully normal signs and symptoms between the attacks were defined as "Recurrent Acute Pancreatitis (RAP)".[9,11] The demographic characteristics of the patients, such as age, gender, family history and systemic diseases, medication used, history of trauma and infection, digestive enzyme-lipid values, clinical findings and symptoms, and radiological examinations were retrospectively examined from the file archive and electronic records for the etiology. The sweat test, serine protease inhibitor of the Kazal (SPINK), protease serine 1 (PRSS1), cystic fibrosis transmembrane regulator (CFTR1) gene results, and records of complications of the disease and prognostic scores of all patients during the attack were evaluated according to the Modified Ranson Criteria (Modified Ranson-DeBanto et al.). ${ }^{[7]}$

Ethical Approval: Ethical Approval was obtained from Çukurova University, Scientific Ethical Board Directorate with the Meeting Number: 44, the Decision Number: 10, Dated: 03.07.2015

\begin{tabular}{|c|c|}
\hline At the diagnosis & At the first $\mathbf{4 8}$ hours \\
\hline 7 age & Blood calcium level $<8.3 \mathrm{mg} / \mathrm{dl}$ \\
\hline $23 \mathrm{~kg}$ & Albumin $<2.6 \mathrm{~g} / \mathrm{dl}$ \\
\hline Leucocyte count $>18.5 \times 10^{3}$ & $\begin{array}{c}\text { Liquid sequestration }>75 \mathrm{ml} / \mathrm{kg} / 48 \\
\text { hours }\end{array}$ \\
\hline Lactate dehydrogenase $>2000 \mathrm{IU} / \mathrm{L}$ & $\begin{array}{l}\text { Elevated blood urea nitrogen }>5 \\
\mathrm{mg} / \mathrm{dl}\end{array}$ \\
\hline \multicolumn{2}{|c|}{$\begin{array}{l}\text { *According to the Modifies Ranson Criteria, the existence of each criterion in the AP score is } 1 \text {; and } \\
0-2 \text { scores; } 8.6 \text { severe AP, and } 1.4 \text { mortality, 3-4 scores } 38.5 \text { severe AP and } 5.8 \text { mortality, } 5-7 \text { scores } 80 \\
\text { sever AP, and } 10 \% \text { mortality risk. }\end{array}$} \\
\hline
\end{tabular}

\section{Statistical Analyses}

The normality of the distribution of the continuous variables was tested with the Shapiro Wilk Test. The Mann Whitney U-test was used to compare the non-normally distributed data between 2 groups. Binary Logistics Regression Analysis was done to investigate the relations between categorical variables to estimate the Odds Ratios and 95\% Cl's. Statistical analyses were done with the SPSS for Windows version 24.0, and $p<0.05$ was considered to be statistically significant.

\section{RESULTS}

A total of 1500/year children with abdominal pain were brought to our Children's Emergency Department, which has an admission of 36000/year, serving a wide area. When the archive records were examined, 53 AP-diagnosed patients, 13 of whom were followed-up in the Pediatric Gastroenterology Unit at our hospital, were included in the study. It was found that a total of 53 patients had attacks 116 times. Our study group covered $1.55 \%$ of the children with abdominal pain. Among the patients, 28 (52.8\%) were female, the mean age was 10.6 \pm 4.4 (the smallest: 0.5 , the oldest: 17.5), and 22 $(41.5 \%)$ had $\geq 2$ attacks. The vital findings of all of the patients were in line with their age during the emergency admission. All the patients had abdominal pain. Epigastric sensitivity was noticed in physical examinations. Vomiting was the most common symptom after abdominal pain, with 31 (58.5\%) patients complaining of vomiting. One patient had an AP history in the family. After the initial evaluation, the patients were followed-up in the Pediatric Gastroenterology Clinics for 15.13 \pm 15.73 (minimum: 3, maximum: 81 ). The prognostic score average was $1.31 \pm 1.18$ (lowest: 0 , highest: 5 ).

The demographic data on the clinical symptoms and findings of the patients and laboratory values at the time of admission are given in Tables $\mathbf{2}$ and $\mathbf{3}$.

Table 2. Demographic data of the clinical symptoms and findings of the patients

\begin{tabular}{lc} 
& $\mathbf{n}(\%)$ \\
\hline Stomachache & $53(100)$ \\
Nausea & $49(92.5)$ \\
Vomiting & $31(58.5)$ \\
Dehydration & $6(11.3)$ \\
Abdominal Defense & $7(13.2)$ \\
Positive sonography finding & $39 / 53$ patients $(73.6)$ \\
Positive Computerized Tomography finding & $30 / 36$ patients $(57.7)$ \\
\hline
\end{tabular}


When the patients were examined in terms of etiology, 10 (18.9\%) had hyperlipidemia, 8 had gallstones, 2 had drug use (Valproic acid and L-Asparaginase), and one had rotavirus infection. One patient developed pancreatitis secondary to blunt force trauma. It was also found that one patient was positive for cystic fibrosis gene mutation. Eight patients were examined with Endoscopic Retrograde Cholangio Pancreatography (ERCP), and cholelithiasis was detected in 6 of them. A total of 11 patients were evaluated with magnetic resonance cholangio pancreatography (MRCP). Choledochus cyst was detected in 1 patient, and pancreas divisium was detected in 1 patient. Five patients underwent genetic examination (SPINK, PRSS1, and CFTR1), and one patient had Homozygote CFTR Gene Mutation. The etiology of 20 patients (38\%) was not detected, and the patients were considered to have idiopathic pancreatitis. Acute pancreatitis etiology is given in Table 4.

When the 22 patients with RAP were compared with those who experienced one AP attack, no statistically significant differences were detected in terms of the gender, age at the time of attack, physical examination, and vital findings ( $p>0.05)$. A total of 19 of the 22 patients were found to have an accompanying systemic disease. The patients with acute pancreatitis and recurrent acute pancreatitis and the relation with the presence of systemic disease are given in Table $\mathbf{5}$.

Table 3. Laboratory values of the patients at admission

\begin{tabular}{|c|c|c|}
\hline & Mean \pm SD & Median (Min-Max) \\
\hline Amylase (IU/L) & $1866.55 \pm 1712.03$ & $1200(89-7448)$ \\
\hline Lipase (U/L) & $669.7 \pm 835.8$ & $395(19-4800)$ \\
\hline Urine amylase (IU/L) & $4041 \pm 6794.3$ & 1505 (334-33472) \\
\hline Triglyceride (mg/dl) & $457.6 \pm 1602.4$ & $77(25-10465)$ \\
\hline $\begin{array}{l}\text { Total cholesterol (mg/ } \\
\text { dl) }\end{array}$ & $142 \pm 78.1$ & $128(15.4-568)$ \\
\hline LDH (U/L) & $205.3 \pm 78.6$ & $189(88-501)$ \\
\hline Total calcium (mg/dl) & $9.7 \pm 1.1$ & $9.6(8-16.1)$ \\
\hline Leukocyte $\left(x 10^{3} / \mu \mathrm{L}\right)$ & $10.6 \pm 4.9$ & $9770(3920-23600)$ \\
\hline Hemoglobin (gr/dl) & $12.6 \pm 1.6$ & $12.7(7.3-15.6)$ \\
\hline $\begin{array}{l}\text { Thrombocyte Ce-(/ } \\
\left.\mathrm{mm}^{3}\right)\end{array}$ & $308949.1 \pm 113154.1$ & $287000(17300-590000)$ \\
\hline Albumin (g/dL) & $3.71 \pm 0.59$ & $3.8(2.1-4.7)$ \\
\hline $\begin{array}{l}\text { Blood urea } \\
\text { nitrogen (mg/dL) }\end{array}$ & $13.16 \pm 7.54$ & $11(4-44)$ \\
\hline
\end{tabular}

\section{Table 4. Etiology of acute pancreatitis}

\begin{tabular}{lcc} 
Etiology & N & $\%$ \\
\hline Hyperlipidemia & 10 & 18.8 \\
Cholelithiasis & 6 & 11.4 \\
Medication & 2 & 3.8 \\
Trauma (blunt) & 1 & 1.9 \\
Infection (Rotavirus) & 1 & 1.9 \\
Cystic fibrosis & 1 & 1.9 \\
Choledoch cyst & 1 & 1.9 \\
Pancreas divisium & 1 & 1.9 \\
Idiopathic & 20 & 38 \\
\hline
\end{tabular}

No statistically significant differences were detected when the laboratory values of our patients were compared with AP and RAP. The comparison of the laboratory values of the patients with acute pancreatitis and recurrent acute pancreatitis are given in Table 6.

\begin{tabular}{|c|c|c|c|c|c|}
\hline \multicolumn{2}{|c|}{ Systemic Diseases Group } & \multirow{2}{*}{$\begin{array}{c}\text { AP } \\
\mathbf{N}(\%) \\
2(6.5)\end{array}$} & \multirow{2}{*}{$\begin{array}{c}\text { RAP } \\
\mathbf{n}(\%) \\
6(27.3)\end{array}$} & \multirow{3}{*}{$\begin{array}{c}\text { OR }[95 \% \mathrm{Cl}] \\
5.44 \\
{[0.98-30.15]}\end{array}$} & \multirow{3}{*}{$\begin{array}{c}\mathbf{P} \\
0.053\end{array}$} \\
\hline \multirow{2}{*}{$\begin{array}{l}\text { Endocrıne and } \\
\text { metabolism disorder }\end{array}$} & Yes & & & & \\
\hline & No & $29(93.5)$ & $16(72.7)$ & & \\
\hline \multirow{2}{*}{$\begin{array}{l}\text { Hematological } \\
\text { oncological disorder }\end{array}$} & Yes & $1(3.2)$ & $1(4.5)$ & \multirow[t]{2}{*}{$\begin{array}{c}1.43 \\
{[0.08-24.14]}\end{array}$} & \multirow[t]{2}{*}{0.805} \\
\hline & No & $30(96.8)$ & $21(95.5)$ & & \\
\hline \multirow{2}{*}{$\begin{array}{l}\text { Central nervous } \\
\text { system disorder }\end{array}$} & Yes & $2(6.5)$ & $0(0)$ & \multirow[t]{2}{*}{$\begin{array}{c}0.57 \\
{[0.49-0.72]}\end{array}$} & \multirow[t]{2}{*}{0.225} \\
\hline & No & $29(93.5)$ & $22(100)$ & & \\
\hline \multirow{2}{*}{ Infectious diseases } & Yes & $2(6.5)$ & $0(0)$ & \multirow[t]{2}{*}{$\begin{array}{c}0.57 \\
{[0.49-0.72]}\end{array}$} & \multirow[t]{2}{*}{0.225} \\
\hline & No & $29(93.5)$ & $22(100)$ & & \\
\hline \multirow{2}{*}{$\begin{array}{l}\text { Rheumatological } \\
\text { immunological } \\
\text { disorder }\end{array}$} & Yes & $2(6.5)$ & $1(4.5)$ & \multirow[t]{2}{*}{$\begin{array}{c}0.69 \\
{[0.06-0.82]}\end{array}$} & \multirow[t]{2}{*}{0.768} \\
\hline & No & $29(93.5)$ & $21(95.5)$ & & \\
\hline \multirow{2}{*}{$\begin{array}{l}\text { Gastroenterological } \\
\text { disorder (non- } \\
\text { pancreatitis) }\end{array}$} & Yes & $0(0)$ & $2(9.1)$ & \multirow[t]{2}{*}{$\begin{array}{c}2.55 \\
{[1.81-3.58]}\end{array}$} & \multirow[t]{2}{*}{0.050} \\
\hline & No & $31(100)$ & $20(90.9)$ & & \\
\hline
\end{tabular}

Table 6. Comparison of the laboratory values of Acute and Recurrent Pancreatitis cases

\begin{tabular}{|c|c|c|c|c|c|}
\hline & \multicolumn{2}{|c|}{ Acute Pancreatitis } & \multicolumn{2}{|c|}{$\begin{array}{l}\text { Recurrent Acute } \\
\text { Pancreatitis }\end{array}$} & \multirow{2}{*}{$\mathbf{P}$} \\
\hline & $n$ & $\begin{array}{c}\text { Median } \\
\text { [25\%-75\%] }\end{array}$ & $\mathbf{n}$ & $\begin{array}{c}\text { Median } \\
{[25 \%-75 \%]}\end{array}$ & \\
\hline Age & 31 & $\begin{array}{c}11 \\
{[8-14]}\end{array}$ & 22 & $\begin{array}{c}10 \\
{[7-15]}\end{array}$ & 0.671 \\
\hline $\begin{array}{l}\text { Amylase 1st } \\
\text { value }\end{array}$ & 31 & $\begin{array}{c}1244 \\
{[563-2600]}\end{array}$ & 22 & $\begin{array}{c}1155.5 \\
{[583-2401]}\end{array}$ & 0.814 \\
\hline $\begin{array}{l}\text { Lipase 1st } \\
\text { value }\end{array}$ & 28 & $\begin{array}{c}343 \\
{[138-971.5]}\end{array}$ & 19 & $\begin{array}{c}428 \\
{[123-1119]}\end{array}$ & 0.974 \\
\hline Urea amylase & 17 & $\begin{array}{c}1112 \\
{[600-2671]}\end{array}$ & 20 & $\begin{array}{c}1710.5 \\
{[914.5-4827]}\end{array}$ & 0.428 \\
\hline Triglyceride & 29 & $\begin{array}{c}80 \\
{[55-138]}\end{array}$ & 20 & $\begin{array}{c}67.5 \\
{[49.5-121.5]}\end{array}$ & 1.000 \\
\hline $\begin{array}{l}\text { Total } \\
\text { cholesterol }\end{array}$ & 29 & $\begin{array}{c}116 \\
{[96-154]}\end{array}$ & 20 & $\begin{array}{c}145 \\
{[121-188.5]}\end{array}$ & 0.047 \\
\hline Calcium & 29 & $\begin{array}{c}9.6 \\
{[9.1-9.9]}\end{array}$ & 22 & $\begin{array}{c}9.65 \\
{[9.2-9.9]}\end{array}$ & 0.710 \\
\hline Leukocyte & 31 & $\begin{array}{c}9900 \\
\text { [5680-14690] }\end{array}$ & 22 & $\begin{array}{c}9220 \\
{[7510-15000]}\end{array}$ & 0.632 \\
\hline Hemoglobin & 31 & $\begin{array}{c}12 \\
{[11.4-13.3]}\end{array}$ & 22 & $\begin{array}{c}13 \\
{[12.3-14.3]}\end{array}$ & 0.055 \\
\hline Thrombocyte & 31 & $\begin{array}{c}313000 \\
{[240000-388000]}\end{array}$ & 22 & $\begin{array}{c}270500 \\
{[244000-367000]}\end{array}$ & 0.836 \\
\hline Total protein & 22 & $\begin{array}{c}6.25 \\
{[6-6.8]}\end{array}$ & 20 & $\begin{array}{c}6.6 \\
{[6.15-6.95]}\end{array}$ & 0.231 \\
\hline Albumin & 24 & $\begin{array}{c}3.6 \\
{[3.25-3.93]}\end{array}$ & 21 & $\begin{array}{c}3.9 \\
{[3.5-4.3]}\end{array}$ & 0.083 \\
\hline $\begin{array}{l}\text { Blood urea } \\
\text { nitrogen }\end{array}$ & 31 & $\begin{array}{c}10 \\
{[9-16]}\end{array}$ & 22 & $\begin{array}{c}11.5 \\
{[8-15]}\end{array}$ & 0.864 \\
\hline Ldh & 27 & $\begin{array}{c}193 \\
{[157-233]}\end{array}$ & 22 & $\begin{array}{c}188 \\
{[140-229]}\end{array}$ & 0.725 \\
\hline $\begin{array}{l}\text { Follow-up } \\
\text { duration }\end{array}$ & 30 & $\begin{array}{c}10 \\
{[6-14]}\end{array}$ & 22 & $\begin{array}{c}49 \\
{[47-64]}\end{array}$ & 0.514 \\
\hline $\begin{array}{l}\text { Prognostic } \\
\text { score }\end{array}$ & 30 & $\left.\begin{array}{c}1 \\
{[0-1]}\end{array}\right]$ & 22 & $\begin{array}{c}1 \\
{[1-3]}\end{array}$ & 0.066 \\
\hline
\end{tabular}




\section{DISCUSSION}

Our study results indicate that although AP is not among the frequent causes of abdominal pain in children, it may be life-threatening. It should be quickly diagnosed in Children's Emergency Departments, and treatment should be started immediately.

It was reported that there were 2-13/100,000 new diagnosed pancreatitis cases in the children's age group every year, and there were increases in these rates in the last two decades. ${ }^{[12]}$ In our study, our patients who were diagnosed with AP accounted for a small number (1.55\%) of those admitting with abdominal pain.

The etiology is highly variable in children's age group, and can be more than one cause in many cases. In patients diagnosed with acute pancreatitis, the etiology is associated with infection, trauma, drug and systemic disease, and RAP is more commonly associated with pancreaticobiliary anomalies, cystic fibrosis, and hereditary pancreatitis. ${ }^{[13-16]}$ In our study, gallstones, infections and drugs were the most common causes of metabolic diseases in our patients with acute AP. One patient had a choledochus cyst, and one patient had pancreas divisium. Among the hereditary causes, CFTR gene mutation was detected in only one patient.

The clinical manifestation was similar in all our patients with both AP and RAP, the most common admission reason was abdominal pain, nausea, and epigastric sensitivity. In the literature, RAP was reported to have developed in 1/3-1/10 of AP patients..$^{[14,17]}$ In our study, RAP developed in 22 patients, with one pancreas divisium, one with choledoch cyst, one with KF diagnosis, and 4 with familial hyperlipidemia. Previous studies reported PRSS-1 and SPINK-1 gene mutations in RAP cases. ${ }^{[18]}$ In our study, these gene mutations were not detected in RAP cases.

In the literature, serum amylase sensitivity varies between $67-100 \%$, its selectivity varies between $85-90 \%$, and serum lipase sensitivity varies between $82-100 \%$ and selectivity varies between $82-100 \%{ }^{[19]}$ In our study, the amylase values of all our patients were at least 3 times higher than the normal upper limit at the time of admission. We found no significant differences between patients with AP and RAP in terms of amylase and lipase values.

In a previous study, elevated liver function test results, especially transaminase values above $150 \mathrm{IU} / \mathrm{L}$, were found to be $95 \%$ compatible with biliary pancreatitis. ${ }^{[20]}$ In our study, it was seen that 6 patients, who had transaminase elevation and cholestasis, also had stones in biliary tract, sphincterotomy was performed with ERCP, and the values were normal after cleaning with a choledochus balloon.

The drug-induced pancreatitis is not frequent, its prognosis is good, and it can limit itself. ${ }^{[21]}$ In our study, 2 patients using L-Asparaginase because of hematological malignancy, and 2 patients who used valproic acid because of epilepsy developed drug-induced pancreatitis. No complications were detected in the follow-up of these patients, and their clinical progression was good.

Abdominal Ultrasonography (US) is a noninvasive and convenient method that can show the dimensions of the pancreas and inflammatory changes in the pancreas tissue, gallbladder and biliary tract. In previous studies, the rate of imaging of the pancreas with US varied between $62-90 \% \cdot{ }^{[19,22]}$ In our study, all patients underwent US at admission. In 21 of the patients who had AP, and in 18 of the RAP patients, pancreatitiscompatible images were detected, and it was determined that the pancreas could not be viewed in the other patients.

MRCP can view biliary tracts that have a diameter of about 1 $\mathrm{mm}$, show gallstones, gall sludge, and anatomical anomalies in the biliary tract. ${ }^{[23]}$ In 6 of the 8 cases who underwent ERCP, stones were found in the biliary tract, choledochus cyst in 1 case, and pancreatic divisium was diagnosed in 1 case.

It was found in our study that AP-related mortality was less than $1 \% .{ }^{[24]}$ We did not lose any patients due to AP and RAP.

As a conclusion, specific causes can be investigated with the increase in diagnostic possibilities in recent years. Imaging and hereditary gene tests have important roles in diagnosis. In the patients with transaminase elevation and cholestasis, biliary tract should be viewed with imaging methods to exclude biliary pathologies, and metabolic causes should be examined. Also, AP should be considered in the differential diagnosis in patients admitting to Child Emergency Department with abdominal pain, and amylase should be examined in case of clinical suspicion.

\section{Limitation}

The most important limitation of this study was that it was planned retrospectively and also there are few sample group in the systemic diseases group categories. Further comprehensive studies are required in which the incidence and etiology of acute pancreatitis are investigated.

\section{ETHICAL DECLARATIONS}

Acknowledgements: There is no any contributor out of Author list.

Authorship: Each author have participated sufficiently in the work to take public responsibility for appropriate portions of the content.

Funding: There is no any funding for this article.

Availability of data and materials: All required data can be found in the article.

Conflict of interest: The authors declare no financial or commercial conflict of interest.

Informed consent: The study has ethical approval from Cukurova University Ethics Committee.

Ethical statement: This article does not contain any studies with human or animal subjects performed by any of the authors. 
Human rights: The study contains no libelous or unlawful statements and does not contain any materials that violate any personal or proprietary rights of any other person or entity.
24. Schütte K, Malfertheiner P. Markers for predicting severity and progression of acute pancreatitis. Best Pract Res Clin Gastroenterol 2008; 22(1):75-90.

\section{REFERENCES}

1. Pekmezci S. Acute pancreatitis approach and treatment. Hepato-Biliary System And Pancreatic Diseases Symposium Series 2002;28:239-62.

2. Yeşim Ö. Acute pancreatitis in childhood. J Child Health Dis 2007;50:14653.

3. Tamer A, Yaylacı S, Demirsoy H, et al. Retrospective Analyses of The Acute Pancreatitis. Sakaryam j. 2011;1(1):17-21.

4. Sekimoto $M$, Takada $T$, Kawarada $Y$, et al. JPN Guidelines for the management of acute pancreatitis:epidemiology, etiology, natural history, and out comepredictors in acute pancreatitis. J Hepatobiliary Pancreat Surg. 2006;13:10-24.

5. Kimura Y, Takada T, Kawarada Y, et al. JPN Guidelines for the management of acute pancreatitis:epidemiology, etiology, natural history, and outcome predictors in acute pancreatitis. Hepatobiliary Pancreat Surg 2006;13(1):10-24.

6. Peery AF, Dellon ES, Lund J, et al. Burden of gastrointestinal disease in the United States:2012 update. Gastroenterology 2012;143:1179.

7. Toouli J, Brooke-Smith M, Bassi C, et al. Guidelines for the management of acute pancreatitis. J Gastroenterol Hepatol 2002;17:15-39.

8. Ippisch HM, Alfaro-Cruz L, Fei L, Zou Y, Thompson T, Abu-EL-Haija M. Hypertriglyceridemia Induced Pancreatitis. Pancreas 2020;49:429-34.

9. Aksu AÜ, Sarı S, Gürken ÖE, Dalgıç B. Pancreatitis in Turkish children:a single center experience. Cukurova Med J. 2019;44(3):991-8.

10.Vepakomma D. Pediatric Pancreatitis:Outcomes and Current Understanding. J Indian Assoc Pediatr Surg. 2020;25:22-7.

11. Morinville VD, Husain SZ, Bai H, et al. INSPPIRE Group. Definitions of pediatric pancreatitis and survey of present clinical practices. J Pediatr Gastroenterol Nutr. 2012;55:261-5.

12. Morinville VD, Barmada MM, Lowe ME. Increasing incidence of acute pancreatitis at an American pediatric tertiary care center:is greater awareness among physicians responsible? Pancreas. 2010;39:5-8.

13. Werlin S, Kugathasan S, Cowan B. Pancreatitis in children. J Pediatr Gastroenterol Nutr. 2003;37:592-5.

14. Weizman Z, Durie P. Acutepancreatitis in childhood. J Pediatr 1988;113:24-9.

15. Pietzak M, Thomas D. Pancreatitis in childhood. Pediatrics Rev 2000;21:406-12.

16. Davenport M. Acute and chronic pancreatitis. Indian J Pediatr. 2002;69:801-7.

17. Lopez M. The changing incidence of acute pancreatitis in children:a single-instituti on perspective. J Pediatr. 2002;140:622-4.

18. Choudari CP, Imperiale TF, Sherman S, Fogel E, Lehman GA. Risk of pancreatitis with mutation of the cystic fibrosis gene. Am J Gastroenterol. 2004;99:1358-63.

19. Koizumi M, Takada T, Kawarada Y, et al. JPN Guidelines for the management of acute pancreatitis:diagnostic criteria for acute pancreatitis. J Hepatobiliary Pancreat Surg. 2006;13:25-32.

20. Bradley EL. A clinically based classification system for acute pancreatitis Summary of the International Symposium on Acute Pancreatitis, Atlanta, Ga, September 11 through 13, 1992. Arch Surg. 1993;128(5):586-90.

21.Balani AR, Grendell JH. Drug-induced pancreatitis:incidence, management and prevention. Drug Saf 2008;31(10):823-37.

22. Elmas $\mathrm{N}$. The role of diagnostic radiology in pancreatitis. European Journal of Radiology. 2001;38:120-32.

23. Taylor CJ, Chen K, Horvath K, et al. ESPGHAN and NASPGHAN Report on the assessment of exocrine pancreatic function and pancreatitis in children. J Pediatr Gastroenterol Nutr 2015;61:144-53. 